\title{
LANDSLIDES IN VITSI (FLORINA) TERRITORY
}

\author{
Ambas V.Ch. ${ }^{1}$, Katsaros E.E. ${ }^{2}$, Alexoudi M.N. ${ }^{3}$, Olasoglou E.M. ${ }^{4}$, Tsapanos \\ T.M. ${ }^{4}$, Koravos G.Ch. ${ }^{4}$, Drakatos G.N. ${ }^{5}$ and Tzamos E.I. ${ }^{6}$ \\ ${ }^{1}$ Region of Western Macedonia, Regional Unit of Florina, 53100 Florina, Greece, \\ v.ambas@florina.pdm.gov.gr \\ ${ }^{2}$ University of Thessaly, Systems Optimization Laboratory, Pedio Areos, 38334 Volos, Greece, \\ ekatsaro@gmail.com \\ ${ }^{3}$ University of Macedonia, 156 Egnatia Street GR-546 36 Thessaloniki, Greece, alexoudi@uom.gr \\ ${ }^{4}$ Aristotle University of Thessaloniki, School of Geology, Department of Geology, Geophysical \\ Laboratory, 54124, Thessaloniki, Greece,eolasoglou@geo.auth.gr, tsapanos@geo.auth.gr, \\ gkoravos@sch.gr \\ ${ }^{5}$ National Observatory of Athens, Institute of Geodynamics, 11810 Thisio, Athens, Greece \\ ${ }^{6}$ Aristotle University of Thessaloniki, School of Geology, Department of Mineralogy and \\ Petrology, 54124 Thessaloniki, Greece,tzamos@geo.auth.gr
}

\begin{abstract}
Landslides can provoke lifeline's performance malfunction, injuries or fatalities and may diminish accessibility to critical facilities and surrounding properties. The scope of this research is to describe and to identify the triggering factors for three landslides along the road from Drosopigi village to the top of Vitsi Mountain at Florina territory using all the available data. Several information were collected for this area, such as the annual rate of the rainfall/ snowfall, the rainfall intensity/day, the seismicity, the geomorphology, the geology, the lithology and the hydrologic conditions. Moreover, in-situ investigations of the landslides, geotechnical and laboratory tests were carried out in three geotechnical boreholes to indentify the soil formations nearby the landslides. Taking into account that the landslides are located $18 \mathrm{~km}, 22 \mathrm{~km}$ and $25 \mathrm{~km}$, away from the epicenters of two historical earthquakes with magnitudes $M w=6.0 \mathrm{k \alpha l}$ 6.5 and also that last winter heavy rainfalls/snowfalls were observed in the area with very low temperatures $\left(-15^{\circ} \mathrm{C}\right)$, slope's failure may have been triggered by an earthquake, by snowfalls/rainfalls or by human activities?

Keywords: Slope failure, Drosopigi- Florina, seismicity, rainfalls, geotechnical investigations.

\section{Пєрі́ $\eta \psi \eta$}

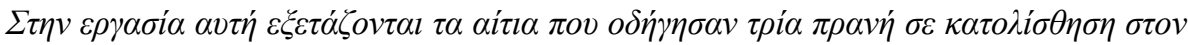



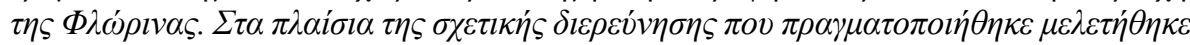

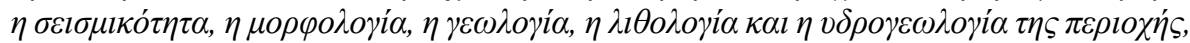

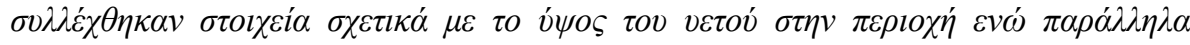




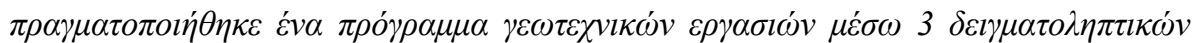

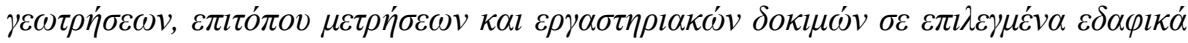



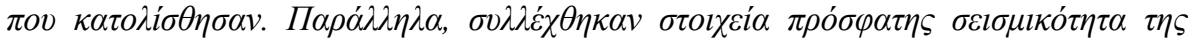

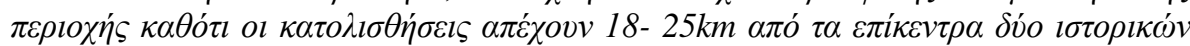



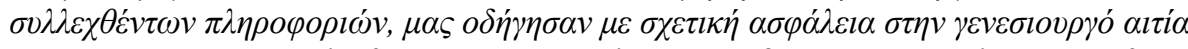

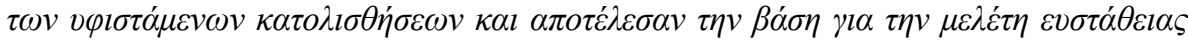

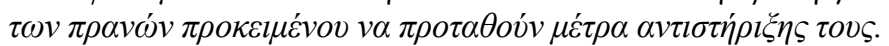

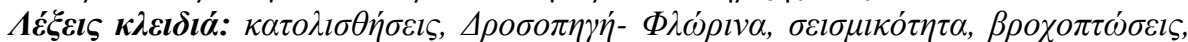
$\gamma \varepsilon \omega \tau \varepsilon \chi v l \kappa \eta ́ ~ \varepsilon ́ \rho \varepsilon v v \alpha$.

\section{Introduction}

Landslides pose important danger to residential areas and to infrastructures that are located very close to unstable slopes, as result of rockfall or debris flow. Landslides can provoke lifeline's performance malfunction (e.g. road closure), injuries or fatalities and may diminish accessibility to critical facilities (hospitals, clinics) and surrounding properties. They can be triggered by natural phenomena (earthquakes, changes in watertables, rapid snowfalls or rainfalls) or by human activities (irrigation, lawn watering, draining of reservoirs, improper excavating or grading on slopes). The prediction of the exact time, location or magnitude of landslide is not feasible because of the complex synergy of geologic, geomorphology, tectonic, hydrologic conditions and soil formations.

The area under consideration is between Florina and Vitsi mountain, in the South-Western part of Florina region, $3 \mathrm{~km}$ from Drosopigi village. In August 2015, three landslides (L1, L2, L3) were observed mainly in the form of rockfalls and debris flow that destroyed part of the road that connect Drosopigi village to the top of Vitsi Mountain. Three geotechnical boreholes (G1, G2, G3) and Standard Penetration Tests (S.P.T) were performed near the landslides together with Laboratory Tests in representative samples (in G2 and G3). The main scope of these in-situ geotechnical investigations and laboratory tests were to evaluate the characteristics of the failed slopes in order to be used for slopes stabilization.

\section{The study area}

The study area is $20 \mathrm{~km}$ from Florina, $3 \mathrm{~km}$ from Drosopigi village, in the South-Western area of Greece. In this area, a number of slope failures, mainly in the form of rockfalls and debris flow, have occurred over the last few decades along the excavated slopes, as result of several natural and manmade hazards. The mountainous terrain with the heavy snowy winters and high rain precipitation in spring and autumn combined with the soil formations in the study area (gneisses and schists) are the primary reasons for the slope failures. The combination of the structurally adverse discontinuities in the weathered front of gneiss, the rugged topography with steep slopes with gradient varied from $40^{\circ}-60^{\circ}$, the under-design and the lack of maintenance of the cut slopes are responsible for the observed slope instability problems.

The impact of rainfall infiltration on slope can change the suction of the soil and the pore-water pressure. Moreover it can alter the main ground-water table, raising the soil unit weight and reducing the anti-shear strength of rock and soil (Yalcin, 2011). Numerous studies have attempted to explain different aspects of rainfall effects (Cascini et al., 2011; Lee and Chi, 2011) such as the internal friction, soil cohesion and cementation reduction. The defined thresholds in a rainfall-induced landslide (RILS) could describe the amount of rainfall that, when reached or exceeded, triggers landslide movement (Sengupta et al., 2010). Intensity (I) and duration (D) of the rainfalls are the most common and useful type of thresholds proposed factors. Terranova et al. (2007) list some rainfall thresholds for landslides while Froehlich et al. (1990) found that shallow slides and slumps on steep slope segments occur when 24-hour rainfall reaches $130-150 \mathrm{~mm}$ or continuous three-day 
rainfall totals 180-200 $\mathrm{mm}$. Slumps, landslides, and debris flows at larger scales, however, were observed only after 24-hour rainfall exceeded $250 \mathrm{~mm}$ or continuous three-day rainfall reached 350 $\mathrm{mm}$ (Froehlich and Starkel, 1987). On the other hand, extensive and simultaneous debris flows occurred after $>300 \mathrm{~mm}$ in a 24 hour rainfall or $>600 \mathrm{~mm}$ of continuous three-day rainfall (Froehlich et al., 1990; Froehlich and Starkel, 1993). Based on Kwong et al. (2004) observation, an intense surface erosion is expected for slopes with rainfall intensity $>50 \mathrm{~mm} /$ day.

The total annual value of rainfalls for the Florina region (Period 1961-2000) according to National Meteorological data is between $500-700 \mathrm{~mm}$ and the rainfall intensity ranges between $51-58 \mathrm{~mm} /$ day (January - May), with peak hourly rainfall 83,7 mm and 102,0 mm (24h) in winter months which is accompanied with an intense surface erosion. The annual rainfalls in the area was $1080,4 \mathrm{~mm}$ during 2010. Heavy snowfalls have been observed in the area in the period 2013-2015 while in 2014 the annual average rainfall in the area was $652,5 \mathrm{~mm}$ with a minimum temperature falling down to $-15^{0} \mathrm{C}$ (winter 2014-2015). According to the hydrological classification of the study area, the hydrographic network is dense with a dendritic drainage pattern and numerous streams in the toe that are responsible for subsurface flows and inner erosion of the bedrock formations.

Field observations, geophysical studies and GPS measurements in the area denote an ongoing tectonic activity (Drakatos et al., 2005; Mountrakis et al., 2006) as well as a rather complicated structural evolution of the area. The earthquakes that occurred (Figure 1) are usually of magnitudes $\mathrm{M}_{\mathrm{w}}<5.0$. However, the broader territory experienced large earthquakes with $\mathrm{Mw}>6.0$ (Papazachos and Papazachou, 2003; The Monthly Bulletins of Earthquakes of the Geophysical Laboratory of Aristotle University of Thessaloniki).

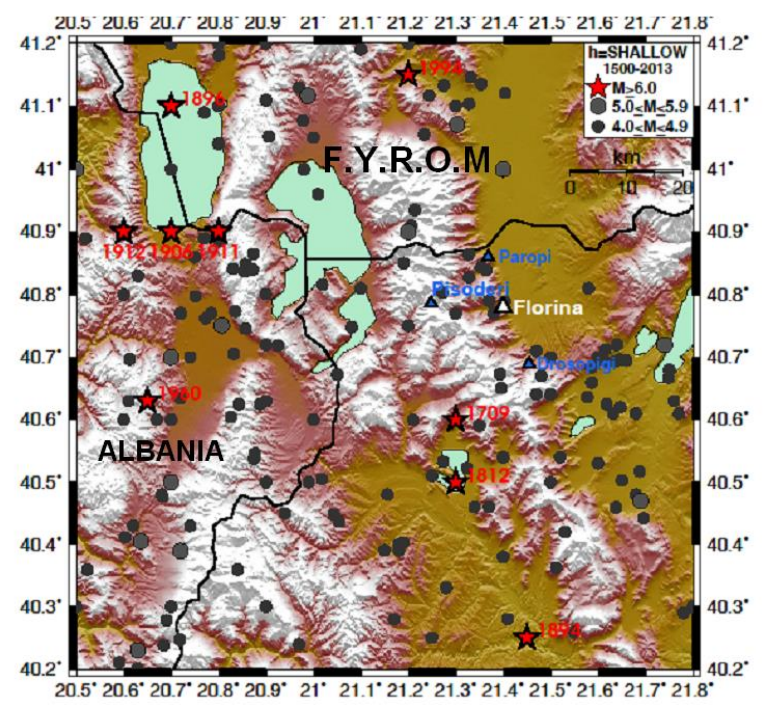

Figure 1 - The epicenters of all earthquakes that occurred in the broader study area during the time span 1500-2013 with magnitudes equal or greater than 4.0. Florina (white triangle), Pisoderi, Parori and Drosopigi villages (blue triangles) are also shown. The epicenters of large events $M w>6.0$ are depicted with red star.

Six large shallow earthquakes (Kozani, 1695, M=6.5, VII; Kastoria, 1709, M=6.0, VII; Kastoria, 1812, $\mathrm{M}=6.5$, VIII; Siatista, 1894, M=6.1, VII; Albania, 1960, M=6.5, VIII+; Grevena, 1995, $\mathrm{M}=6.6, \mathrm{IX}+$ ) occurred in the broader territory in the last 300 years with the two of them (1709 and 1812 events) close to Drosopigi village, $18 \mathrm{Km}, 22 \mathrm{Km}, 25 \mathrm{~km}$ from G1, G2, G3 landslides, respectively.

In August 2015, three landslides (Fig. 2) were observed in the study area (L1, L2, L3) mainly in the form of rockfalls and debris flow that destroyed part of the road near Drosopigi village. The 
maximum rainfall intensity was $44.4 \mathrm{~mm} /$ day (6-8-2015) lower than the Froehlich et al. (1990) rainfall thresholds for shallow slides and slumps on steep slopes, but quite similar to $50 \mathrm{~mm} / \mathrm{day}$ for intense surface erosion. As it is generally observed, shallow earthquakes generate rockfalls and can also trigger landslides if their magnitude is $\mathrm{M}_{\mathrm{w}}>4.0$ (Esposito et al., 2000). For that reason an investigation of the recent seismic activity of the area was performed. There was not any remarkable earthquake activity in the area during 2014-2015. Moreover, no human activities to trigger landslides such as irrigation, lawn watering, draining of reservoirs were noticed during the in-situ investigations.

\section{Geological and seismotectonic setting of the area}

According to the geotectonic manifestation of the Internal Hellenides zones in Northern Greece (Fi gure 2), the region belongs to Pelagonian (Pl) zone (Mountrakis, 1983). According to the geological features, the study roadline lies mainly on Carboniferous - early Triassic formations (Gneisses and Schists). Nearby the landslides, three geotechnical boreholes (G1, G2, G3) and Standard Penetration Tests (S.P.T) were performed together with Laboratory Tests.

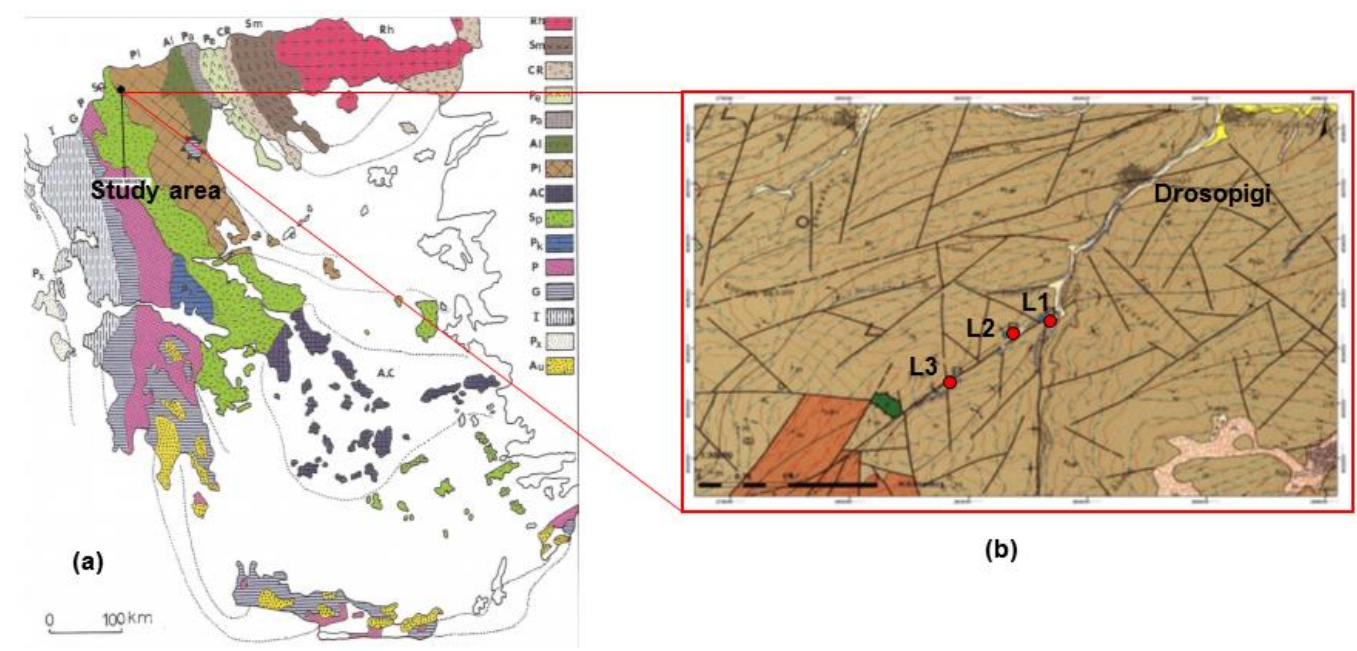

Figure 2 - a) The geotectonic manifestation of the Internal Hellenide zones in Northern Greece, b) Location of geotechnical boreholes (L1, L2, L3).

The geologic formations of the area are mainly gneisses (both orthogneisses and paraneisses, with intercalations of schists in the form of lenses or layers) and amphibolites in smaller extend. The orthogneisses are characterized by granoblastic-porphyroid to augen texture and their main mineralogical composition is quartz, feldspars (perthitized microcline and acid poikilitic plagioclases) and muscovite. In smaller proportions, epidotes (pistacite, clinozoisite, allanite), chloritized biotite, sphene, zircon and metallic minerals also occur as secondary minerals. The paragneisses are equigranular rocks with abundant quartz and often with lenticular concentrations of acid plagioclases and muscovite. The partial or total transformation of biotite into chlorite results to the formation of muscovite chlorite schists by retrograde metamorphism. Tourmaline, epidote and metallic minerals also occur in insignificant proportions. The amphibolites are characterized by granoblastic-nematoblastic texture and oriented to occasionally microfolded structure. Their main mineralogical constituents are amphibolites (actinolite-tremolite) and epidote (clinozoisite). Feldspars participate in certain amphibolites. 


\section{Hydrological Conditions}

Ten automatic meteorological stations (A.M.S.) operate within the Florina territory. The A.M.S. of Tropeuhos is on the road from Florina to Vitsi and the closest to the three landslides. The time series for precipitation is 47 years, from 1969 to 2016.

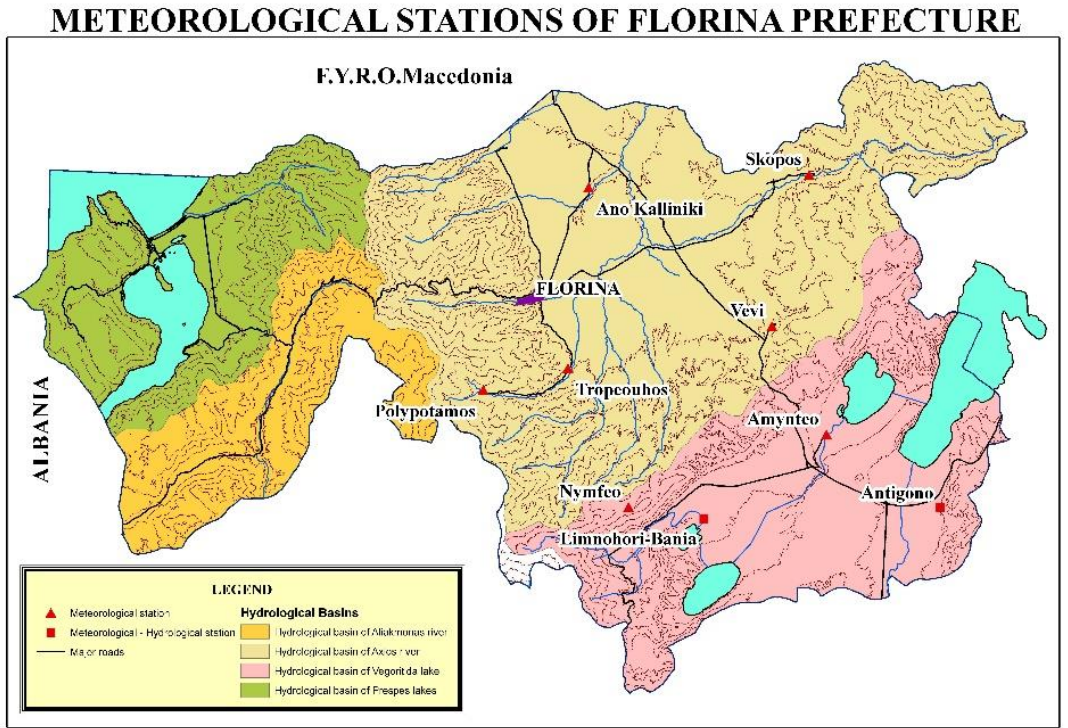

Figure 3 - Study area, Prefecture of Florina, Western Macedonia, Greece.

Table 1 - Precipitation of Tropehos meteorological station.

\begin{tabular}{|l|r|r|r|}
\hline & $\begin{array}{l}\text { Mean } \\
\text { Value } \\
1969- \\
2016\end{array}$ & 2014 & 2015 \\
\hline Jan & 52,3 & 15,2 & 75,0 \\
\hline Feb & 53,1 & 13,0 & 62,0 \\
\hline Mar & 59,0 & 83,6 & 95,0 \\
\hline Apr & 63,5 & 125,6 & 44,0 \\
\hline May & 62,5 & 47,2 & 20,0 \\
\hline Jun & 38,0 & 58,6 & 51,0 \\
\hline Jul & 34,2 & 72,8 & 18,0 \\
\hline Aug & 33,3 & 30,2 & 110,0 \\
\hline Sep & 50,7 & 163,2 & 120,0 \\
\hline Oct & 75,9 & 102,4 & 122,0 \\
\hline Nov & 71,5 & 89,0 & 50,0 \\
\hline Dec & 66,9 & 112,0 & 3,0 \\
\hline SUM & 661,0 & 912,8 & 770,0 \\
\hline
\end{tabular}

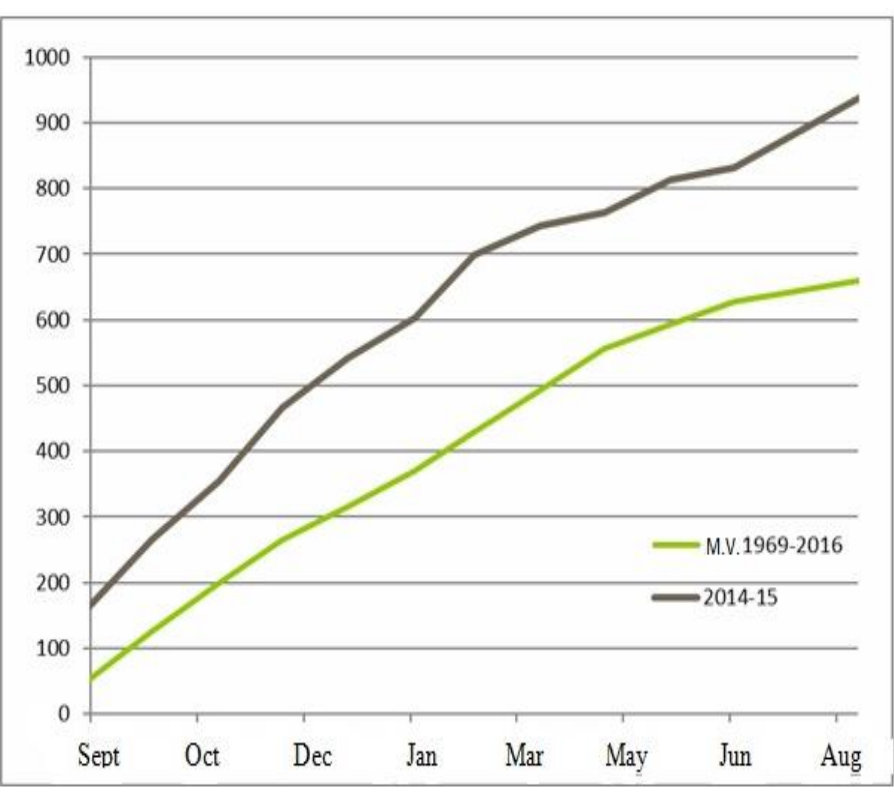

Figure 4 - Cumulative Precipitation of the Tropeuhos AMS. 
From Table 1 we see conclude that:

- 2014 was a very rainy year $(912 \mathrm{~mm})$ by $138 \%$ more that the average of the time series (661 mm).

- The hydrological year $2014-15$ was $142 \%$ more $(941 \mathrm{~mm})$ that the average of the time series $(661 \mathrm{~mm})$.

- The winter 2014-15 (Sept-Feb) was $163 \%$ more $(699 \mathrm{~mm})$ that the average of the time series $(429 \mathrm{~mm})$.

Table 2 - Precipitation of Tropeuhos meteorological station.

\begin{tabular}{|c|c|c|c|c|c|c|c|c|c|c|c|c|c|}
\hline & Jan & Feb & Mar & Apr & May & Jun & Jul & Aug & Sept & Oct & Noe & Dec & \\
\hline $\begin{array}{c}\text { Average } \\
1969-16\end{array}$ & 52,3 & 53,1 & 59,0 & 63,5 & 62,5 & 38,0 & 34,2 & 33,3 & 50,7 & 75,9 & 71,5 & 66,9 & 661,0 \\
\hline 2014 & 15,2 & 13,0 & 83,6 & 125,6 & 47,2 & 58,6 & 72,8 & 30,2 & 163,2 & 102,4 & 89,0 & 112,0 & 912,8 \\
\hline 2015 & 75,0 & 62,0 & 95,0 & 44,0 & 20,0 & 51,0 & 18,0 & 110,0 & 120,0 & 122,0 & 50,0 & 3,0 & 770,0 \\
\hline
\end{tabular}

\section{In-situ investigations and laboratory tests}

Inventory is cost and time consuming process, with large uncertainties due to the poor knowledge of several components (e.g. structural characteristics of the rocks, the state of weathering and the properties of the soil-rock interface) and the complexity of interrelated terrain parameters (e.g., hydrological conditions). It requires several technical visits to describe existing landslides, to define the susceptible slopes for landslides, to recognize the type of the potential slope's movement (e.g. sliding, toppling etc.) and to correlate the failure modes with the likelihood of each failure and the probable extent of landslides. In-situ investigations or field measurements and laboratory tests can provide valuable information about the geometrical (e.g., slope height and angle) and geotechnical characteristics (material type, cohesion, friction angle, type and properties of discontinuities etc.) of individual slopes.

In our case, three landslides are observed and investigated (L1, L2 and L3), as indicated in Figure 5. The landslide (L1) is about $10.0 \mathrm{~m}$ long in the longitudinal direction, $1 \mathrm{~m}$ wide in the latitudinal direction and is occurred in a slope with gradient $23^{\circ}$. It is a combination of debris slide, rock slide and rock topple. Landslide (L2) is a debris flow, about 5.0m long in the longitudinal direction, and $1 \mathrm{~m}$ wide in the latitudinal direction and is occurred in a slope with gradient $21^{\circ}$. Landslide (L3) is about $6.0 \mathrm{~m}$ long in the longitudinal direction; $0.3-0.7 \mathrm{~m}$ wide in the latitudinal direction, is translation type slide but develops into debris flow. The gradient of the slope in L3 site is $45^{\circ}$ and the area beside the landslide is mostly covered by vegetation and trees. The altitude of the area ranges between 1080 and $1260 \mathrm{~m}$.

Near the existing landslides (L1, L2, L3), three sampling drills (Geotechnical Boreholes) were performed in G1 (4040'01.1' 'N latitude, 21026'14.7' 'E longitude), in G2 (40039'51.0' $\mathrm{N}$ latitude, 21025'51.2', E longitude) and in G3 (4039'24.2' ' N latitude, 21025'12.3' E longitude) locations using hydraulic JOY 22 SULLIVAN LTD Drill Rigs (Figure 6 and Figure 7). Moreover, several tests as a Standard Penetration Test (S.P.T) (in G1, G2 and G3) and Laboratory Tests (Grain size distribution, Atterberg limits on the soil samples and Point load- 3 sample each) were carried out in representative samples (in G2 and G3). 




Figure 5 - A general view of Vitsi landslides (L1, L2, L3).

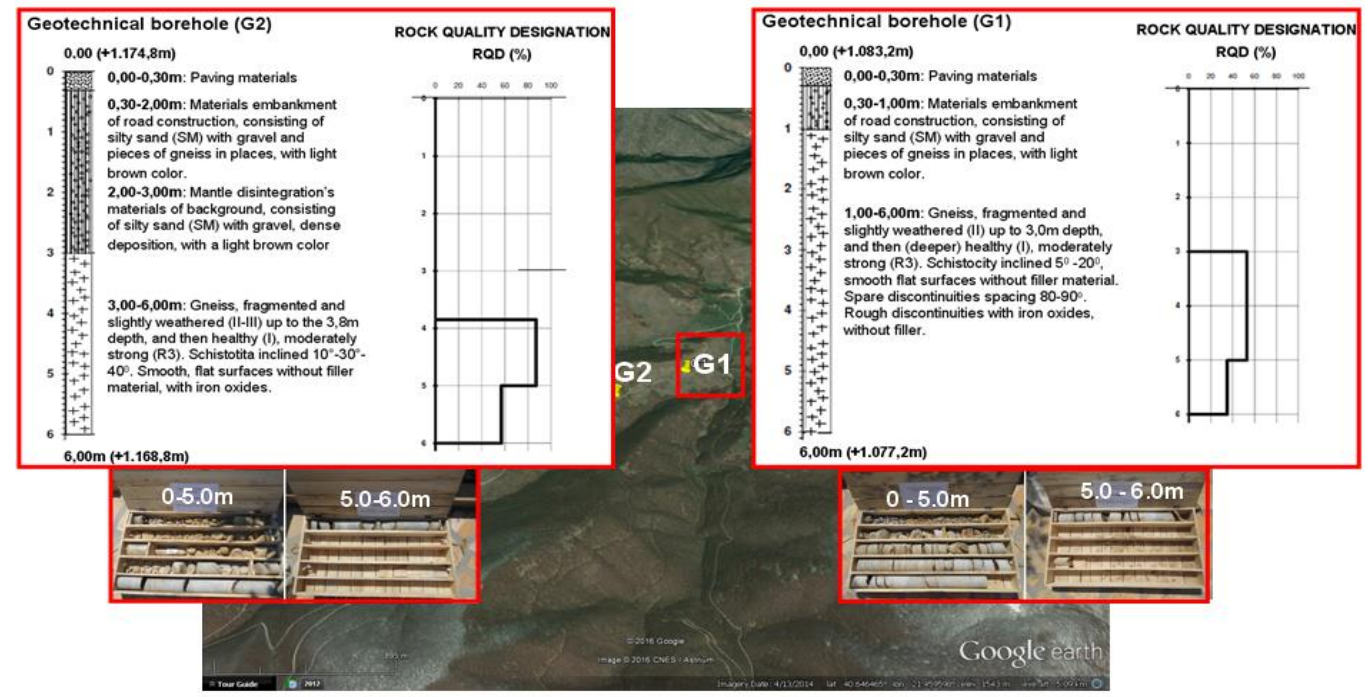

Figure 6 - Typical soil profiles in G1 and G2 location/ Photos of Test Samples (Tsirekas, 2015).

According to laboratory tests, three soil layers were identified. The $1^{\text {st }}$ layer is the Embankment fill with depths ranges from $0.30 \mathrm{~m}$ to $1.0 \mathrm{~m}(\mathrm{G} 1)$ and $0.30 \mathrm{~m}$ to $2.0 \mathrm{~m}(\mathrm{G} 2)$. The $2^{\text {nd }}$ layer is the disintergradated gneiss or silty sand (SM) with gravel ( $\mathrm{N}_{\mathrm{SPT}} \square=50 / 15$ and $50 / 5$ - in two tests) with $\mathrm{LL}=28.1 \%, \mathrm{PL}=23.6 \%, \mathrm{PI}=4.5 \%$ and with average $16 \%$ of gravels, $62 \%$ of sand and $22 \%$ of siltyclay. The $3^{\text {rd }}$ layer is Gneiss with different degree of fragmentation with $\operatorname{Is}_{(50)}$ ranges between 0,75 $2,1 \mathrm{MPa}$ in 3 Point Load Tests. Groundwater level, in landslides' area, is below $20 \mathrm{~m}$. 
Permeability of gneiss is originally very low, but orogeny - related deep - seated fracture or shear zone in these rocks serves as good passway or reservoir of groundwater. Their yields of groundwater estimates to be $50-500 \mathrm{~m}^{3} / \mathrm{d}$. Permeability and yields of groundwater in schist, amphibolite and phyllite are remarkably lower than those of gneiss because of the intercalted clay bed within fracture zone and foliation (Soon-Hak Choi, 1997), while silty sands permeability is between $10^{-8}$ and $510^{-}$ ${ }^{6} \mathrm{~m} / \mathrm{s}$.

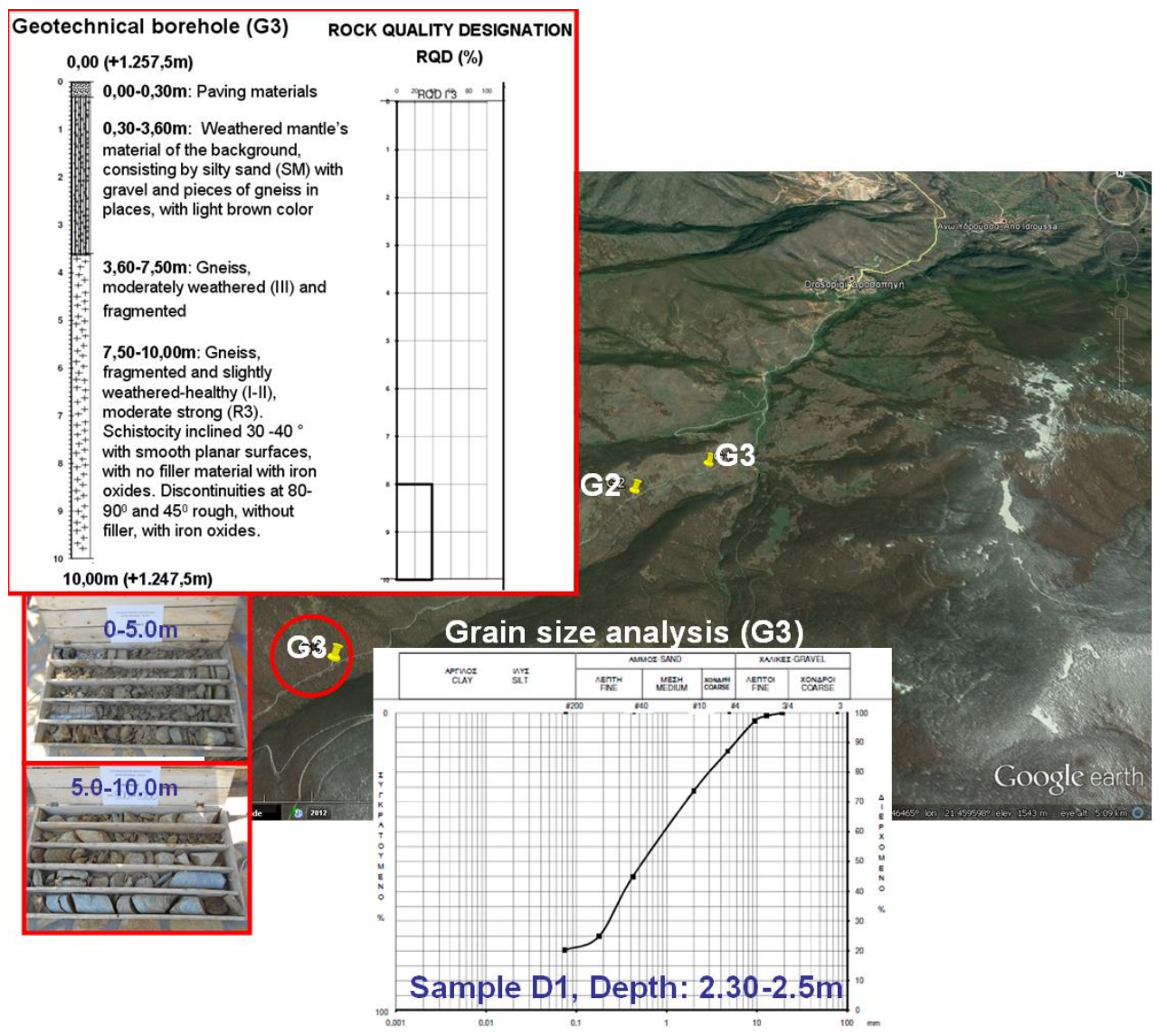

Figure 7 - Typical soil profile (G3 location)/ Photos of Test Samples/ Grain size analysis (Tsirekas, 2015).

\section{Discussion and Conclusions}

The geology, the lithology, the hydrology, the in-situ geotechnical investigations and the laboratory tests of the landslides area conclude that the three landslides generated in Florina territory which caused severe damages to the roadline from Drosopigi village to the top of Vitsi Mountain can be attribute mainly to natural phenomena. Taking into account that there was no remarkable seismic activity in the area during 2014-2015, we can conclude that the damages from landslides along the road Drosopigi-top of Vitsi mountain are not related to earthquakes.

Therefore, the combination of the structurally discontinuities in the weathered gneiss formations existing in the area, the low winter temperatures in the area together with the heavy precipitations (winter 2014-2015), , together with the lack of maintenance of the cut slopes are additive factors for progressive slope deterioration and for slope instability problems. 


\section{Acknowledgements}

The authors would like to express their sincere thanks to our colleague Dr. Th. Mavrommatis for providing the meteorological data. The present paper prepared in the framework of RECALL project which is financially supported by the European Commission/Directorate - General Humanitarian Aid and Civil Protection- ECHO, Ref. No: 2014| PREV/32 - RECALL.

\section{References}

Cascini, L., Cuomo, S. and Sala, M.D., 2011. Spatial and temporal occurrence of rainfall-induced shallow landslides of flow type: a case of Sarno-Quindici, Italy, Geomorphology, 126(1-2), 148-158. http://dx.doi.org/10.1016/j.geomorph.2010.10.038.

Drakatos, G., Voulgaris, N., Pirli, M., Melis, N. and Karakostas, B., 2005. 3-D crustal velocity structure in northwestern Greece, Pageoph., 162, 37-51.

Esposito, E.S.P., Simonelli, A.L., Mastrolorenzo, G. and Iaccarino, G., 2000. Landslides and other surface effects induced by the 1997, Umbria-Marche seismic sequence, Engineering Geology, 58, 353-376.

Froehlich, W. and Starkel, L., 1987. Normal and extreme monsoon rains-their role in the shaping of the Darjeeling Himalaya, Studia Geomerphologica Carpatho-Balcanica, 21, 129-156 (Kakow).

Froehlich, W., Gil, E., Kasza, I. and Starkel, L., 1990. Thresholds in the transformation of slopes and river channels in the Darjeeling Himalaya, India, Mountain Research and Development, 10, 301-312.

Froehlich, W. and Starkel, L., 1993. The effects of deforestation on slope and channel evolution in the tectonically active Darjeeling Himalaya, Earth Surface Processes and Landforms, 18, 285-290.

Keefer, D.K., 1984. Landslides caused by earthquakes, Geol, Soc. Am. Bull., 95, 406-421.

Kwong, A.K.L., Wang, M., Lee, C.F. and Law, K.T., 2004. A review of landslide problems and mitigation measures in Chongqing and Hong Kong: similarities and differences, Engineering Geology, 76, 27-39.

Lee, Y.F. and Chi, Y.Y., 2011. Rainfall-induced landslide risk at Lushan, Taiwan, Engineering Geology, 123, 113-121. http://dx.doi.org/ 10.1016/j.enggeo.2011.03.006.http: //dx.doi.org/ 10.1016/ j.enggeo.2011.03.006.

Mountrakis, D., Tranos, M., Papazachos, C., Thomaidou, E., Karagianni, E. and Vamvakaris, D., 2006. Neotectonic and seismological data concerning major active faults and stress regions in Northern Greece. In: Robertson, A.H.E. and Mountrakis, D., eds., Tectonic Development of the Eastern Mediterranean Region, Geological Society London, Special Publication, 260, 649-670, The Geological Society of London 2006.

Mountrakis, D., 1983. Structural geology of the north Pelagonian zone s.I. and geotectonic evolution of the internal Hellenides, unpubl., 'Habilitation'.

Papazachos, B.C. and Papazachou, C.C., 2003. The earthquakes of Greece (in Greek), Ziti Publications, Thessaloniki, $286 \mathrm{pp}$.

Sengupta, A., Gupta, S. and Anbarasu, K., 2010. Rainfall thresholds for the initiation of landslide at Lanta Khola in north Sikkim, India, Natural Hazards, 52, 31-42.

Soon-Hak, Choi., 1997. Characteristics of hydrogeologic units of groundwater resources in the Republic of Korea. In: Engineering Geology and the Environment, Marinos, Koukis, Tsiambaos and Stournaras, eds., Balkema, Rotterdam, ISBN 9054108770.

Terranova, O., Antronico, L. and Gullà, G., 2007. Landslide triggering scenarios in homogeneous geological contexts: the area surrounding Acri (Calabria, Italy), Geomorphology, 87(4), 250-267.

Tsirekas, D. 2015. Geotechnical survey-study rehabilitation of embankments breaking on the Provincial Road Florina - Vitsi, 74 pp.

Yalcin, A., 2011. A geotechnical study on the landslides in the Trabzon Province, NE, Turkey, Applied Clay Science, 52, 11-19. http://dx.doi.org/10.1016/j.clay.2011.01.015. 